\title{
Responses of soil respiration to elevated carbon dioxide and nitrogen addition in young subtropical forest ecosystems in China
}

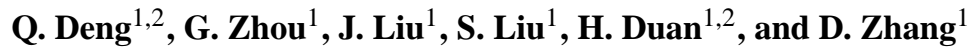 \\ ${ }^{1}$ South China Botanical Garden, Chinese Academy of Sciences, Guangzhou 510650, China \\ ${ }^{2}$ Graduate University of Chinese Academy of Sciences, Beijing 100039, China
}

Received: 16 June 2009 - Published in Biogeosciences Discuss.: 24 August 2009

Revised: 28 December 2009 - Accepted: 10 January 2010 - Published: 25 January 2010

\begin{abstract}
Global climate change in the real world always exhibits simultaneous changes in multiple factors. Prediction of ecosystem responses to multi-factor global changes in a future world strongly relies on our understanding of their interactions. However, it is still unclear how nitrogen $(\mathrm{N})$ deposition and elevated atmospheric carbon dioxide concentration $\left[\mathrm{CO}_{2}\right]$ would interactively influence forest floor soil respiration in subtropical China. We assessed the main and interactive effects of elevated $\left[\mathrm{CO}_{2}\right]$ and $\mathrm{N}$ addition on soil respiration by growing tree seedlings in ten large open-top chambers under $\mathrm{CO}_{2}$ (ambient $\mathrm{CO}_{2}$ and $700 \mu \mathrm{mol} \mathrm{mol}^{-1}$ ) and nitrogen (ambient and $100 \mathrm{~kg} \mathrm{Nha}^{-1} \mathrm{yr}^{-1}$ ) treatments. Soil respiration, soil temperature and soil moisture were measured for 30 months, as well as above-ground biomass, root biomass and soil organic matter (SOM). Results showed that soil respiration displayed strong seasonal patterns with higher values observed in the wet season (April-September) and lower values in the dry season (October-March) in all treatments. Significant exponential relationships between soil respiration rates and soil temperatures, as well as significant linear relationships between soil respiration rates and soil moistures (below 15\%) were found. Both $\mathrm{CO}_{2}$ and $\mathrm{N}$ treatments significantly affected soil respiration, and there was significant interaction between elevated $\left[\mathrm{CO}_{2}\right]$ and $\mathrm{N}$ addition $(p<0.001, p=0.003$, and $p=0.006$, respectively). We also observed that the stimulatory effect of individual elevated $\left[\mathrm{CO}_{2}\right]$ (about $29 \%$ increased) was maintained throughout the experimental period. The positive effect of $\mathrm{N}$ addition was found only in 2006 (8.17\% increased), and then had been weakened over time. Their combined effect on soil respiration (about 50\% increased) was greater than
\end{abstract}

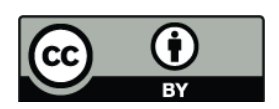

Correspondence to: D. Zhang

(zhangdeq@scbg.ac.cn) the impact of either one alone. Mean value of annual soil respiration was $5.32 \pm 0.08,4.54 \pm 0.10,3.56 \pm 0.03$ and $3.53 \pm 0.03 \mathrm{~kg} \mathrm{CO}_{2} \mathrm{~m}^{-2} \mathrm{yr}^{-1}$ in the chambers exposed to elevated $\left[\mathrm{CO}_{2}\right]$ and high $\mathrm{N}$ deposition $(\mathrm{CN})$, elevated $\left[\mathrm{CO}_{2}\right]$ and ambient $\mathrm{N}$ deposition (CC), ambient $\left[\mathrm{CO}_{2}\right]$ and high $\mathrm{N}$ deposition $(\mathrm{NN})$, and ambient $\left[\mathrm{CO}_{2}\right]$ and ambient $\mathrm{N}$ deposition (CK as a control), respectively. Greater above-ground biomass and root biomass was obtained in the $\mathrm{CN}, \mathrm{CC}$ and $\mathrm{NN}$ treatments, and higher soil organic matter was observed only in the $\mathrm{CN}$ treatment. In conclusion, the combined effect of elevated $\left[\mathrm{CO}_{2}\right]$ and $\mathrm{N}$ addition on soil respiration was apparent interaction. They should be evaluated in combination in subtropical forest ecosystems in China where the atmospheric $\mathrm{CO}_{2}$ and $\mathrm{N}$ deposition have been increasing simultaneously and remarkably.

\section{Introduction}

Soil respiration consists of autotrophic root respiration and heterotrophic respiration which is associated with decomposition of litter, roots and soil organic matter (SOM) (Bernhardt et al., 2006). It is one of the largest fluxes in the global carbon cycle $\left(68-75 \times 10^{15} \mathrm{~g} \mathrm{C} \mathrm{yr}^{-1}\right)$ (Raich and Schlesinger, 1992). Global modeling studies have demonstrated that even a small change in soil $\mathrm{CO}_{2}$ emissions due to global change has the potential to impact atmosphere $\mathrm{CO}_{2}$ accumulation and global carbon budget (Woodwell et al., 1998 Cox et al., 2000; Cramer et al., 2001). Since global climate change in the real world always exhibits concurrent changes in multiple factors (Shaw et al., 2002; Norby and Luo 2004), understanding regulations of soil respiration by multiple global change factors is necessary to project global carbon cycling in the future. 
The atmospheric carbon dioxide concentration $\left[\mathrm{CO}_{2}\right]$ has increased by approximately $35 \%$ during the past decades and is predicted to reach $700 \mu \mathrm{mol} \mathrm{mol}^{-1}$ by the end of this century (IPCC, 2001). Numerous experiments have been carried out to investigate the responses of soil respiration to elevated $\left[\mathrm{CO}_{2}\right]$ (Lin et al., 2001; King et al., 2004; Astrid et al., 2004; Bernhardt et al., 2006; Pregitzer et al., 2008). Elevated $\left[\mathrm{CO}_{2}\right]$ can reduce diffusive conductance (Pearson et al., 1995; Niklaus et al., 1998) and stomatal conductance of the leaves (Saxe et al., 1998), which leads to decreased rates of canopy transpiration and increased soil moisture in $\mathrm{CO}_{2}$ enrichment plots (Bunce, 2004). As a result, soil microbial processes such as litter decomposition and nutrient mineralization were stimulated (Niklaus et al., 1998). Soil respiration was closely related to photosynthetic activity (Moyano et al., 2008). Elevated $\left[\mathrm{CO}_{2}\right]$ could enhance photosynthetic assimilation rates, and hence increased the above- and below-ground biomass production. The increase in belowground biomass would increase $\mathrm{CO}_{2}$ loss from the soil (Luo et al., 1996; Edwards and Norby, 1999) and enhance carbon release into the rhizosphere by root exudation (van Ginkel et al., 2000; Allard et al., 2006). The increase in aboveground biomass would produce more litter-fall. All these will contribute to higher soil respiration under elevated $\left[\mathrm{CO}_{2}\right](\mathrm{Zak}$ et al., 2000).

However, in Asia, due to the rapid expansion of industrial and agricultural activities, the use and emission of reactive $\mathrm{N}$ increased from $14 \mathrm{Tg} \mathrm{N} \mathrm{yr}^{-1}$ in 1961 to $68 \mathrm{Tg} \mathrm{N} \mathrm{yr}^{-1}$ in 2000 and is expected to reach $105 \mathrm{Tg} \mathrm{N} \mathrm{yr}^{-1}$ in 2030 (Zheng et al., 2002). Atmospheric $\mathrm{N}$ deposition $\left(\mathrm{NH}_{4}^{+}-\mathrm{N}\right.$ and $\left.\mathrm{NO}_{3}^{-}-\mathrm{N}\right)$ in southern China has also been increasing remarkably (Galloway et al., 2004; Mo et al., 2006, 2007; Chen and Mulder, 2007) and reached $30-73 \mathrm{~kg} \mathrm{~N} \mathrm{ha}^{-1} \mathrm{yr}^{-1}$ in precipitation in some subtropical forests (Ma, 1989; Ren et al., 2000; Xu et al., 2001). How the increase of $\left[\mathrm{CO}_{2}\right]$ would influence soil respiration under high ambient $\mathrm{N}$ deposition in subtropical forests in China remains unclear.

Plants require more nutrients for plant growth under the elevated $\mathrm{CO}_{2}$ treatments. If increases in photosynthetic carbon gain under elevated $\left[\mathrm{CO}_{2}\right]$ are not matched by the increases in nutrient supply and/or increases in plant nutrientuse efficiency, the effect of $\mathrm{CO}_{2}$ enrichment to plant growth may decline or weaken over time (Norby et al., 1986; Murray et al., 2000; Luo et al., 2004; Bernhardt et al., 2006), which also would affect soil respiration. However, soil moisture might become lower with increased diffusive conductance and stomatal conductance of the leaves under $\mathrm{N}$ addition (Li et al., 2004), which will reduce soil microbial activity (Kucera et al., 1971). $\mathrm{N}$ addition also leads to soil acidification (Huber et al., 2004) especially in tropical forests where the soils are often highly acidic, which will further affect soil microbial activity and SOM decomposition rate (Anderson and Joergensen, 1997; Kemmitt et al., 2006). In addition, it had been reported that $\mathrm{N}$ addition decreased root biomass and soil microbial biomass over time (Mo et al., 2007, 2008).
High $\mathrm{N}$ deposition might reduce litter decomposition rate (Mo et al., 2006). As a result, the effects of $\mathrm{N}$ addition to soil respiration are still not conclusive. Both increases, decreases, and unchanged in soil respiration with $\mathrm{N}$ additions to forest soils have been reported (Bowden et al., 2000 and 2004; Burton et al., 2004; Micks et al., 2004; Cleveland and Townsend, 2006; Mo et al., 2007 and 2008). Mo et al. (2007) recently showed that the response of soil respiration to atmospheric $\mathrm{N}$ deposition may vary depending on the rate of $\mathrm{N}$ deposition and the degree of initial soil nutrient status. How $\mathrm{N}$ deposition and elevated $\left[\mathrm{CO}_{2}\right]$ would interactively influence soil respiration in subtropical forests has not been well investigated.

We conducted a two-factor experiment investigating the interactive effects of elevated $\left[\mathrm{CO}_{2}\right]$ and $\mathrm{N}$ deposition on soil respiration in young subtropical forest ecosystems. We hypothesized that

1. elevated $\left[\mathrm{CO}_{2}\right]$ would stimulate soil respiration due to greater soil $\mathrm{C}$ input;

2. the stimulatory effect would be sustained over time due to the high ambient $\mathrm{N}$ deposition in subtropical China; and

3. the combined effect of elevated $\left[\mathrm{CO}_{2}\right]$ and $\mathrm{N}$ addition would be greater than the impact of either one alone due to positive interaction. To test the hypotheses, we measured soil respiration, soil temperature and soil moisture for 30 months, as well as above-ground biomass, root biomass and SOM in an open-top chamber experiment.

\section{Materials and methods}

\subsection{Site description}

The experiment was conducted at South China Botanical Garden, Chinese Academy of Sciences, Guangzhou, China $\left(23^{\circ} 20^{\prime} \mathrm{N}\right.$ and $\left.113^{\circ} 30^{\prime} \mathrm{E}\right)$. The area is characterized by a typical south subtropical monsoon climate, with annual precipitation ranging from $1600 \mathrm{~mm}$ to $1900 \mathrm{~mm}$, of which nearly $80 \%$ falls in the hot-humid wet/rainy season (AprilSeptember) and 20\% in the dry season (October-March). Total annual solar radiation reaches $4.37-4.60 \mathrm{GJ} \mathrm{m}^{-2} \mathrm{yr}^{-1}$ in the photosynthetic active radiation (PAR) range. The mean annual temperature is $21.5^{\circ} \mathrm{C}$, and the mean relative humidity is $77 \%$ (Liu et al., 2008).

\subsection{Open-top chamber design}

Ten open-top chambers were built for this experiment. Each $3-\mathrm{m}$ diameter chamber is 3-m tall and $0.7-\mathrm{m}$ deep. The above-ground part was wrapped with impermeable and transparent plastic sheets, leaving the top of the chamber totally 
Table 1. Height and basal diameter of the plant seedlings among all treatments at the beginning of the experiment (mean \pm standard deviations). The treatments are: $\mathrm{CK}=$ control, $\mathrm{NN}=$ high $\mathrm{N}, \mathrm{CC}=$ elevated $\mathrm{CO}_{2}, \mathrm{CN}=$ elevated $\mathrm{CO}_{2}+$ high $\mathrm{N}$.

\begin{tabular}{|c|c|c|c|c|c|}
\hline Parameters & Species & $\mathrm{CN}$ & $\mathrm{CC}$ & $\mathrm{NN}$ & $\mathrm{CK}$ \\
\hline \multirow{6}{*}{ Height (cm) } & Acmena acuminatissima & $25.54 \pm 0.47$ & $24.40 \pm 0.57$ & $25.03 \pm 0.84$ & $24.83 \pm 1.09$ \\
\hline & Castanopsis hystrix & $67.91 \pm 1.39$ & $68.83 \pm 1.25$ & $64.13 \pm 2.28$ & $68.50 \pm 2.45$ \\
\hline & Ormosia pinnata & $19.47 \pm 0.55$ & $18.96 \pm 0.71$ & $18.53 \pm 0.85$ & $18.47 \pm 0.77$ \\
\hline & Pinus massoniana & $49.33 \pm 2.33$ & $48.31 \pm 2.18$ & $47.41 \pm 2.16$ & $49.59 \pm 2.42$ \\
\hline & Schima superba & $38.04 \pm 1.10$ & $37.23 \pm 1.86$ & $36.34 \pm 1.29$ & $35.94 \pm 1.00$ \\
\hline & Syzygium hancei & $58.62 \pm 2.19$ & $58.60 \pm 1.75$ & $59.00 \pm 2.43$ & $60.47 \pm 2.41$ \\
\hline \multirow{6}{*}{ Basal diametre $(\mathrm{cm})$} & Acmena acuminatissima & $0.28 \pm 0.01$ & $0.26 \pm 0.01$ & $0.27 \pm 0.01$ & $0.28 \pm 0.01$ \\
\hline & Castanopsis hystrix & $0.65 \pm 0.03$ & $0.62 \pm 0.02$ & $0.55 \pm 0.02$ & $0.61 \pm 0.02$ \\
\hline & Ormosia pinnata & $0.53 \pm 0.01$ & $0.54 \pm 0.01$ & $0.53 \pm 0.02$ & $0.52 \pm 0.02$ \\
\hline & Pinus massoniana & $0.59 \pm 0.04$ & $0.58 \pm 0.04$ & $0.59 \pm 0.03$ & $0.57 \pm 0.05$ \\
\hline & Schima superba & $0.45 \pm 0.01$ & $0.46 \pm 0.02$ & $0.49 \pm 0.04$ & $0.46 \pm 0.02$ \\
\hline & Syzygium hancei & $0.56 \pm 0.02$ & $0.52 \pm 0.02$ & $0.57 \pm 0.02$ & $0.59 \pm 0.03$ \\
\hline
\end{tabular}

open. Light intensity in the chamber was $97 \%$ of that in open space and no spectral change was detected. Measured rainfall intensity was identical inside and outside of the chambers and the temperature was not significantly different. The below-ground part was delimited by concrete brick wall that prevented any lateral or vertical water and/or element fluxes with the outside surrounding soil. Three holes at the bottom of the wall were connected to a stainless steel water collection box. Holes were capped by a $2-\mathrm{mm}$ net to prevent losses other than those of leachates. In the treatment chambers with elevated $\left[\mathrm{CO}_{2}\right]$, the additional $\mathrm{CO}_{2}$ was distributed from a $\mathrm{CO}_{2}$ tank by a transparent pipe with pinholes. A big fan was connected to the pipe to ensure equal distribution of $\mathrm{CO}_{2}$ in the entire chamber. Air was introduced into the chambers via the fan at an exchange rate of about 1.5 chamber volumes per minute. The $\mathrm{CO}_{2}$ flux from the tank was controlled by a flow meter and the $\mathrm{CO}_{2}$ concentrations in the chambers were periodically checked by using a Li-Cor 6400 (Li-COR, Inc., Lincoln, Nebraska, USA).

The soils used in the experiment were collected from a nearby ever-green broad-leaved forest after harvesting from 26 February 2005 to 3 March 2005. Simultaneously, the soil was collected as three different layers (0-20, 20-40 and 40$70 \mathrm{~cm}$ depth) that were homogenised separately and used to fill the below-ground part of the chambers. The lateritic soil with its chemical properties (before the soil was collected) was shown in Liu et al. (2008). On 10 March 2005, one to two year old seedlings grown in a nursery were transplanted in the chambers without damaging the roots. All the chambers were planted with 48 randomly selected seedlings with 8 seedlings each of the following 6 species: Castanopsis hystrix Hook.f. \& Thomson ex A.DC, Syzygium hancei Merr. et Perry, Pinus massoniana Lambert, Schima superba Gardn. and Champ., Acmena acuminatissima (Blume) Merr. et Perry, and Ormosia pinnata (Lour.) Merr. These 6 species were selected because they are all native and all widely distributed in southern China. No significant difference in height and basal diameter of the plant seedlings was found among all treatments at the beginning of the experiment (Table. 1).

\subsection{Experiment design}

We used a completely randomized design with four treatments considering two levels of $\mathrm{CO}_{2}$ and two levels of $\mathrm{N}$. Since we have ten open-top chambers, the replication number for the treatments was not equal. For elevated $\left[\mathrm{CO}_{2}\right]$ and high $\mathrm{N}$ deposition $(\mathrm{CN})$, and elevated $\left[\mathrm{CO}_{2}\right]$ and ambient $\mathrm{N}$ deposition (CC), 3 chambers were used, respectively. For ambient $\mathrm{CO}_{2}$ and high $\mathrm{N}$ deposition (NN), and no treatment as a control (CK), 2 chambers were used, respectively. The elevated $\mathrm{CO}_{2}$ treatments were achieved by supplying additional $\mathrm{CO}_{2}$ from a tank until reaching a $\mathrm{CO}_{2}$ concentration of ca. $700 \mu \mathrm{mol} \mathrm{mol}^{-1}$ in the chambers. The $\mathrm{N}$ addition treatments were achieved by spraying seedlings once a week for a total amount of $\mathrm{NH}_{4} \mathrm{NO}_{3}$ at $100 \mathrm{~kg} \mathrm{Nha}^{-1} \mathrm{yr}^{-1}$. No other fertilizer was used. Since the walls of the chambers belowground parts blocked lateral and vertical water fluxes, the seedlings were watered with tap water. All the chambers received the same amount of water as the CK chambers. These treatments started in April 2005.

\subsection{Soil respiration measurement}

Four PVC soil collars $\left(80 \mathrm{~cm}^{2}\right.$ in area and $5 \mathrm{~cm}$ in height $)$ were permanently installed $3 \mathrm{~cm}$ into the soil in each chamber in April 2006. The distance between adjacent collars was more than $50 \mathrm{~cm}$. To eliminate the influence of plants on soil respiration, all living plants in the collars were removed one day before soil respiration measurement. From 26 June 2006 to 22 December 2008, soil respiration was measured once a week using a Li-Cor 6400 infrared gas analyzer 
(Li-COR, Inc., Lincoln, Nebraska, USA) connected with a Li-Cor 6400-09 soil respiration chamber $(9.55 \mathrm{~cm}$ diameter) (Li-COR, Inc., Lincoln, Nebraska, USA). The measurements were made between 9:00 am and 12:00 pm local time. The soil respiration chamber (with a foam gasket) was put on the PVC soil collars making an air-tight seal. Soil respiration was measured three times for each soil collar. Soil respiration in a treatment chamber was calculated as the mean of four collar measurements (the measurement at four collars in a chamber differed by less than $5 \%$ at any measurement period). Soil temperature at $5 \mathrm{~cm}$ below the soil surface was also monitored with a thermocouple sensor attached to the respiration chamber during the soil respiration measurement. Volumetric soil moisture of the top $5 \mathrm{~cm}$ soil layer was measured on five random locations within a treatment chamber using a PMKit (Tang et al., 2006) at the same time when the soil respiration measurements were being taken.

\subsection{Annual soil respiration calculation}

Annual or semiannual soil respiration for each treatment was estimated by summing the products of weekly mean soil respiration and the number of days between samples. The soil respiration measurements made between 9:00 am and 12:00 pm represent the daytime averages, based on a study at a similar site where diurnal pattern of soil respiration was measured (Tang et al., 2006). Because the measurement of soil respiration began in 26 June 2006, we only estimated semiannual soil respiration from July to December in 2006.

\subsection{Above-ground biomass, root biomass and soil organic matter}

Plant height and basal diameter were measured at the time of planting in early March 2005 and then were assessed five times in August 2005, November 2005, May 2006, September 2007 and January 2008. Plant height was measured from the soil surface to the tip of the apical bud and the basal diameter was assessed at the soil surface. To measure plant biomass, one tree of each species in every chamber was harvested in January 2008. This tree was separated into roots, stems and leaves. Tree samples were oven-dried at $60^{\circ} \mathrm{C}$ before being weighed. The biomass of each harvested tree was calculated with sample biomass using dry/fresh ratio. Strong correlations among dry biomass for each component part, basal area and height existed irrespective of size in trees harvested, which were stated in the equation (Whittake and Woodwell, 1986; Wen et al., 1997):

$W=a\left(D^{2} H\right)^{b}$

Where $W$ is dry biomass of each tree components including root, stem and leaf $\left(\mathrm{kg} \mathrm{m}^{-2}\right), D$ is plant basal diameter (cm), $H$ is height (cm), and $a, b$ are regression coefficients.
The biomass of other un-harvested trees was calculated separately by using their height and basal diameter into the equation above. Here plant biomass is the total biomass of all trees in a chamber irrespective of species. The above-ground biomass was the sum of stem and leaf biomass.

Soil samples were collected on November, 2008 to determine soil organic matter (SOM). Three samples $(0-20 \mathrm{~cm}$ depth) were collected randomly in each chamber. Each sample was composted from three cores using a standard soil probe $(2.5 \mathrm{~cm}$ inside diameter). The composite samples were gently mixed. SOM was determined following Walkley Black's wet digestion method (Nelson and Sommers, 1982).

\subsection{Data analysis}

Repeated measures ANOVA with Tukey's HSD test was used to examine treatment effects (including the main effects of $\mathrm{CO}_{2}, \mathrm{~N}$, time-of-season and their interactions) on soil respiration rate, soil temperature and soil moisture. Repeated measures ANOVA with Tukey's HSD test was used to examine treatment difference in soil respiration rate, soil temperature and soil moisture. Standard t-test was used to test the seasonal difference in means of soil respiration rate, soil temperature and soil moisture. To compare the effects among our three measured years, One-way ANOVA with Tukey's HSD test was used to test the treatment difference in annual or semiannual soil respiration, as well as root biomass and soil organic matter.

Both linear and nonlinear regression models were used to examine the relationship between soil respiration rates and soil temperature and moisture (Tang et al., 2006; Li et al., 2008). Simple models with soil temperature and soil moisture were performed. An exponential equation and a linear equation were used:

$R=\operatorname{aexp}(b T)$

$R=a M+b$

Where $R$ is soil respiration rate $\left(\mu \mathrm{mol} \mathrm{CO}_{2} \mathrm{~m}^{-2} \mathrm{~s}^{-1}\right), T$ is soil temperature $\left({ }^{\circ} \mathrm{C}\right), M$ is soil moisture $(\%)$ and $a, b$ are constants fitted to the regression equation.

The index of soil respiration response to temperature was also described by the $Q_{10}$ value, defined as the difference in respiration rates over a $10{ }^{\circ} \mathrm{C}$ interval. $Q_{10}$ value was calculated using the exponential relationship between soil respiration and soil temperature (Lloyd and Taylor, 1994; Buchmann, 2000; Xu and Qi, 2001):

$Q_{10}=\exp (10 b)$

Where $b$ is the constant fitted into Eq. 2. One-way ANOVA test was used to compare $b$ values among treatments.

All analyses were conducted using SPSS 10.0 (SPSS, Chicago, Ill) for Microsoft Windows. 
Table 2. Significance of the impacts of $\mathrm{CO}_{2}$ (effect of individual elevated $\left[\mathrm{CO}_{2}\right]$ ), $\mathrm{N}$ (effect of individual $\mathrm{N}$ addition), $\mathrm{CO}_{2} * \mathrm{~N}$ (the interactive effect between elevated $\left[\mathrm{CO}_{2}\right]$ and $\mathrm{N}$ addition) and season on soil respiration $(R)$, soil temperature $(T)$ and soil moisture $(M)$ in the repeated measures ANOVA.

\begin{tabular}{llcccccc}
\hline & & \multicolumn{2}{c}{$R$} & \multicolumn{2}{c}{$T$} & \multicolumn{2}{c}{$M$} \\
& & $F$ & $p$ & $F$ & $p$ & $F$ & $p$ \\
\hline \multirow{2}{*}{ Annual } & $\mathrm{CO}_{2}$ & 121.45 & $<0.001$ & 0.21 & 0.643 & 30.45 & $<0.001$ \\
& $\mathrm{~N}$ & 10.31 & 0.003 & 0.04 & 0.846 & 7.20 & 0.024 \\
& $\mathrm{CO}_{2} * \mathrm{~N}$ & 7.24 & 0.006 & 0.01 & 0.930 & 1.95 & 0.263 \\
& $\mathrm{Season}$ & 261.58 & $<0.001$ & 520.86 & $<0.001$ & 276.11 & $<0.001$ \\
& & & & & & & \\
\multirow{5}{*}{ Wet season } & $\mathrm{CO}_{2}$ & 75.25 & $<0.001$ & 1.03 & 0.312 & 10.01 & 0.002 \\
& $\mathrm{~N}$ & 7.26 & 0.008 & 0.02 & 0.898 & 3.26 & 0.073 \\
& $\mathrm{CO}_{2} * \mathrm{~N}$ & 0.41 & 0.524 & 0.08 & 0.782 & 0.39 & 0.535 \\
& $\mathrm{CO}_{2}$ & 54.30 & $<0.001$ & 0.01 & 0.906 & 21.38 & $<0.001$ \\
& $\mathrm{~N}$ & 3.47 & 0.064 & 0.02 & 0.881 & 5.00 & 0.026 \\
& $\mathrm{CO}_{2} * \mathrm{~N}$ & 18.55 & $<0.001$ & 0.01 & 0.936 & 1.82 & 0.179 \\
\hline
\end{tabular}

Table 3. Mean soil respiration rate, mean soil temperature at $5 \mathrm{~cm}$ below the soil surface and mean soil moisture of the top $5 \mathrm{~cm}$ soil layer under different $\mathrm{CO}_{2}$ and $\mathrm{N}$ treatments (mean \pm standard deviations). Standard deviation within each treatment showed the dispersion among open-top chambers employed for each treatment. $n=3$ for the $\mathrm{CN}$ and $\mathrm{CC}$ treatments, $n=2$ for the NN treatment and CK. Mean values within a row with different lowercase letter have significant treatment differences at $\alpha=0.05$ level. Means values within each column indicated by the asterisk show significant seasonal differences at $\alpha=0.05$ level. The treatments are: $\mathrm{CK}=$ control, $\mathrm{NN}=$ high $\mathrm{N}, \mathrm{CC}=$ elevated $\mathrm{CO}_{2}$, $\mathrm{CN}=$ elevated $\mathrm{CO}_{2}+$ high $\mathrm{N}$.

\begin{tabular}{llllll}
\hline treatment & Time & $\mathrm{CN}$ & $\mathrm{CC}$ & $\mathrm{NN}$ & $\mathrm{CK}$ \\
\hline Soil respiration rate & Wet season & $4.61 \pm 0.10 \mathrm{a}^{*}$ & $4.12 \pm 0.08 \mathrm{~b}^{*}$ & $3.34 \pm 0.03 \mathrm{c}^{*}$ & $2.94 \pm 0.05 \mathrm{~d}^{*}$ \\
$\left(\mu \mathrm{mol} \mathrm{CO} \mathrm{m}^{-2} \mathrm{~s}^{-1}\right)$ & Dry season & $2.91 \pm 0.05 \mathrm{a}^{*}$ & $2.36 \pm 0.03 \mathrm{~b}^{*}$ & $1.89 \pm 0.03 \mathrm{c}^{*}$ & $\begin{array}{l}2.10 \pm 0.04 \mathrm{bc}^{*} \\
\end{array}$ \\
& Annual means & $3.76 \pm 0.07 \mathrm{a}$ & $3.24 \pm 0.04 \mathrm{~b}$ & $2.56 \pm 0.04 \mathrm{c}$ & $2.52 \pm 0.02 \mathrm{c}$ \\
\hline & Wet season & $24.20 \pm 0.15 \mathrm{a}^{*}$ & $25.23 \pm 0.17 \mathrm{a}^{*}$ & $25.28 \pm 0.11 \mathrm{a}^{*}$ & $25.25 \pm 0.21 \mathrm{a}^{*}$ \\
Soil temperature $\left({ }^{\circ} \mathrm{C}\right)$ & Dry season & $17.26 \pm 0.08 \mathrm{a}^{*}$ & $17.31 \pm 0.09 \mathrm{a}^{*}$ & $17.35 \pm 0.13 \mathrm{a}^{*}$ & $17.33 \pm 0.11 \mathrm{a}^{*}$ \\
& Annual means & $21.23 \pm 0.12 \mathrm{a}$ & $21.18 \pm 0.11 \mathrm{a}$ & $21.29 \pm 0.07 \mathrm{a}$ & $21.25 \pm 0.19 \mathrm{a}$ \\
\hline & Wet season & $24.31 \pm 0.60 \mathrm{a}^{*}$ & $25.52 \pm 0.36 \mathrm{a}^{*}$ & $22.51 \pm 0.76 \mathrm{~b}^{*}$ & $23.48 \pm 0.82 \mathrm{ab}$ \\
Soil moisture $(\%)$ & Dry season & $17.77 \pm 0.64 \mathrm{ab} *$ & $18.80 \pm 0.24 \mathrm{a}^{*}$ & $14.72 \pm 0.50 \mathrm{c}^{*}$ & $17.35 \pm 0.95 \mathrm{~b}^{*}$ \\
& Annual means & $20.84 \pm 0.56 \mathrm{~b}$ & $22.16 \pm 0.22 \mathrm{a}$ & $18.58 \pm 0.90 \mathrm{c}$ & $20.42 \pm 0.896 \mathrm{~b}$ \\
\hline
\end{tabular}

\section{Results}

\subsection{Soil temperature and moisture}

Soil temperature and moisture exhibited clear seasonal patterns $(p<0.001$ for both). Soil was warm and wet from April through September (the wet season) and became cool and dry from October to the March of the next year (the dry season) (Tables 2 and 3; Fig. 1). The seasonality of soil temperature and moisture was consistent with the seasonal patterns of air temperature and precipitation (Liu et al, 2008). Annual mean soil temperature and soil moisture were $21.25 \pm 0.19^{\circ} \mathrm{C}$ and $20.42 \pm 0.90 \%$, respectively in the CK chambers. There was no treatment effect on soil temperature $(p>0.05$ for all treatments). However, elevated
$\left[\mathrm{CO}_{2}\right]$ significantly increased soil moisture $(p<0.001)$, and $\mathrm{N}$ addition significantly decreased soil moisture $(p=0.024)$. The CN treatments did not alter the regimes of soil moisture $(P=0.263)$ (Tables. 2 and 3$)$.

\subsection{Soil respiration}

Soil respiration also exhibited a clear seasonal pattern with the maximum respiration rates occurred during the summer when soil temperature and moisture were high; the minimum respiration rates occurred during the winter when soil temperature and moisture were low ( $p<0.001$ for both) (Table 3 ; Fig. 1). In all treatments, significant exponential relationships between soil respiration rate and soil temperature 

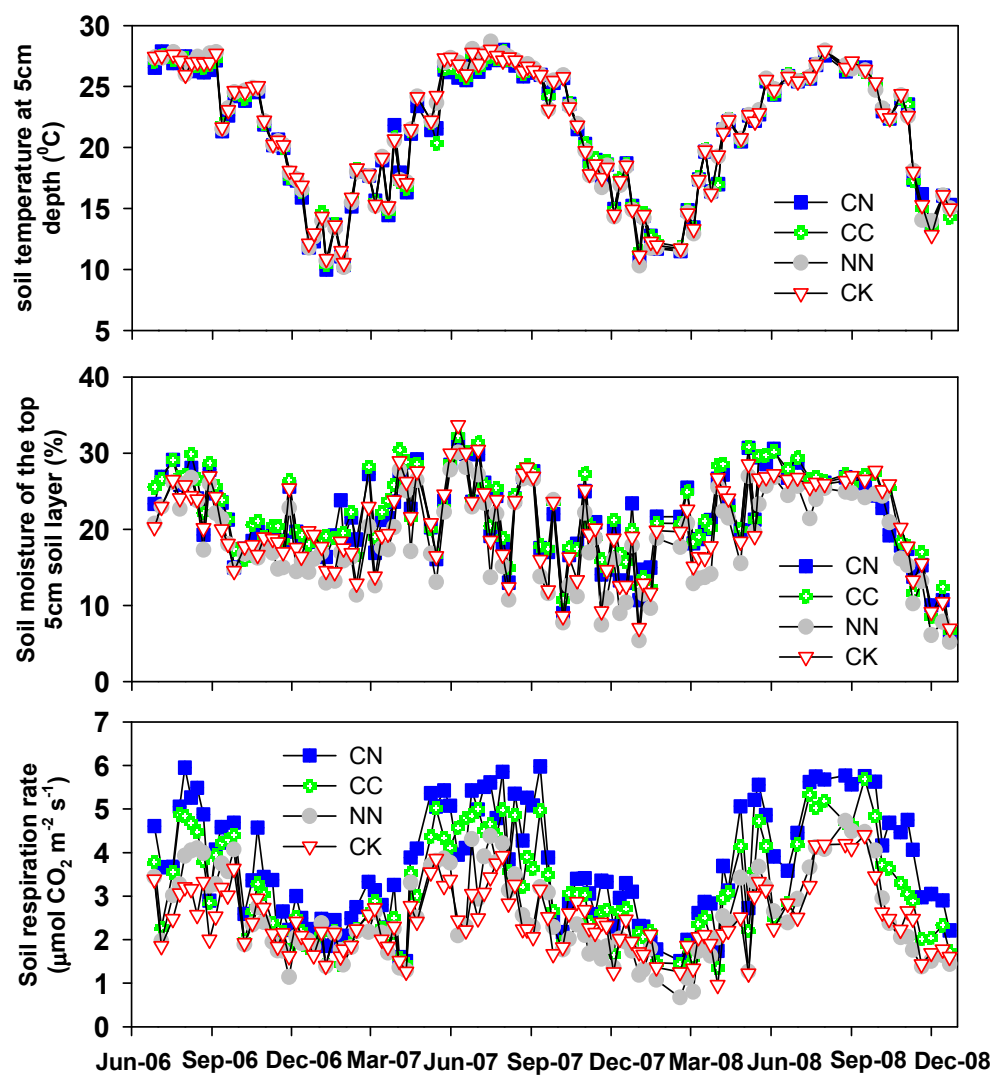

Fig. 1. Seasonal dynamics of soil temperature at $5 \mathrm{~cm}$ below the soil surface, soil moisture of the top $5 \mathrm{~cm}$ soil layer and soil respiration rate under different $\mathrm{CO}_{2}$ and $\mathrm{N}$ treatments. The treatments are: $\mathrm{CK}=$ control, $\mathrm{NN}=$ high $\mathrm{N}, \mathrm{CC}=$ elevated $\mathrm{CO}_{2}, \mathrm{CN}=\mathrm{elevated} \mathrm{CO}_{2}+$ high $\mathrm{N}$.

were found ( $p<0.001$ for both) (Table 4; Fig. 2). Temperature sensitivity $\left(Q_{10}\right)$ was estimated as $1.87,1.90,1.86$ and 1.57 in the $\mathrm{CN}, \mathrm{CC}, \mathrm{NN}$ and $\mathrm{CK}$ treatments, respectively. By analyzing subsets of data with low and high soil moisture content we found a significant positive linear relationship between soil respiration rate and soil moisture when soil moisture was below $15 \%$ (Table 4; Fig. 3).

The repeated measures ANOVA showed that both $\mathrm{CO}_{2}, \mathrm{~N}$ treatments and their interaction affected soil respiration significantly $(F=121.45, \quad p<0.001 ; \quad F=$ $10.31, \quad p=0.003$; and $F=7.24, \quad p=0.006$, respectively) (Table 2). Soil respiration rate was the highest in the $\mathrm{CN}$ chambers $\left(3.76 \pm 0.07 \mu \mathrm{mol} \mathrm{CO} \mathrm{C}_{2} \mathrm{~m}^{-2} \mathrm{~s}^{-1}\right)$, followed by the $\mathrm{CC}$ chambers $\left(3.24 \pm 0.04 \mu \mathrm{mol} \mathrm{CO}_{2} \mathrm{~m}^{-2} \mathrm{~s}^{-1}\right)$, $\mathrm{NN}$ and the control chambers (CK) $(2.56 \pm 0.04$ and $2.52 \pm 0.02 \mu \mathrm{mol} \mathrm{CO}_{2} \mathrm{~m}^{-2} \mathrm{~s}^{-1}$, respectively) for the experimental period (Table 3). In addition, $\mathrm{CO}_{2}$ treatment affected soil respiration significantly in both wet and dry season ( $p<0.001$, for both), but $\mathrm{N}$ treatment affected soil respiration significantly only in wet season $(p=0.008)$ and their interaction affected soil respiration significantly only in dry season $(p<0.001)$ (Table 2$)$.
The mean value of annual soil respiration was $5.32 \pm 0.08$, $4.54 \pm 0.10,3.56 \pm 0.03$ and $3.53 \pm 0.03 \mathrm{~kg} \mathrm{CO}_{2} \mathrm{~m}^{-2} \mathrm{yr}^{-1}$ in the $\mathrm{CN}, \mathrm{CC}, \mathrm{NN}$ and $\mathrm{CK}$ treatments, respectively (Table 5). By analyzing each treatment's annual or semiannual soil respiration in the latter half of 2006, 2007 and 2008, we observed that annual or semiannual soil respiration in the $\mathrm{CN}$ and $\mathrm{CC}$ treatments increased by $49.24-51.38 \%$ and $27.24-28.45 \%$, respectively (Table 5). It seems that the stimulatory effect of the $\mathrm{CN}$ and $\mathrm{CC}$ treatments on soil respiration was sustained over our study period. However, the effect of the $\mathrm{NN}$ treatment on soil respiration was increased in 2006 (8.17\%), with no change in 2007 and 2008 (2.32\% and $-0.55 \%$, respectively) (Table 5). Obviously, the effect of the NN treatment on soil respiration had been weakened over time.

\subsection{Above-ground biomass, root biomass and soil organic matter}

Both of above- and below-ground biomass in the CN CC and NN treatments was significantly higher than that in the CK chambers at our study sites. Mean above-ground biomass was $4.37,3.11,3.41$ and $2.62 \mathrm{~kg} \mathrm{~m}^{-2}$ in the $\mathrm{CN}, \mathrm{CC}, \mathrm{NN}$ and CK treatment in January 2008, respectively (Fig. 4). Mean 
Table 4. Model for relationships between the soil respiration $(R)$ and soil temperature at $5 \mathrm{~cm}$ below the soil surface $(T)$ and soil moisture of the top $5 \mathrm{~cm}$ soil layer $(M)$ (mean \pm standard deviations). Standard deviation within each treatment showed the dispersion among open-top chambers employed for each treatment. $n=3$ for the $\mathrm{CN}$ and CC treatments, $n=2$ for the NN treatment and CK. Mean values of $b$ in the exponential equation $(R=a \exp (\mathrm{bT}))$ within a column with different lowercase letter have significant treatment differences at $\alpha=0.05$ level. $\mathrm{R}^{2}$ is the determination of coefficient. The treatments are: $\mathrm{CK}=$ control, $\mathrm{NN}=$ high $\mathrm{N}, \mathrm{CC}=$ elevated $\mathrm{CO}_{2}, \mathrm{CN}^{2}=\mathrm{elevated} \mathrm{CO}_{2}+$ high $\mathrm{N}$. Unit: $\mu \mathrm{mol} \mathrm{CO}_{2} \mathrm{~m}^{-2} \mathrm{~s}^{-1}$ for $R ;{ }^{\circ} \mathrm{C}$ for $T$ and $\%$ for $M$.

\begin{tabular}{lccccc}
\hline Treatment & $a$ & $b$ & $Q_{10}$ & $p$ & $R^{2}$ \\
\hline a) Soil moisture $>15 \%: R=a \exp (b T)$ & & & & & \\
CN & $1.0155 \pm 0.027$ & $0.0627 \pm 0.001 \mathrm{a}$ & 1.87 & $<0.001$ & 0.68 \\
CC & $0.8085 \pm 0.061$ & $0.0641 \pm 0.001 \mathrm{a}$ & 1.90 & $<0.001$ & 0.69 \\
NN & $0.66 \pm 0.017$ & $0.062 \pm 0.002 \mathrm{a}$ & 1.86 & $<0.001$ & 0.67 \\
CK & $0.9904 \pm 0.030$ & $0.0449 \pm 0.001 \mathrm{~b}$ & 1.57 & $<0.001$ & 0.57 \\
Treatment & $a$ & $b$ & $n$ & $p$ & $R^{2}$ \\
b) Soil moisture $<15 \%: R=a M+b$ & & & & & \\
CN & $0.1545 \pm 0.007$ & $1.1638 \pm 0.071$ & 13 & $<0.001$ & 0.61 \\
CC & $0.1389 \pm 0.008$ & $0.701 \pm 0.044$ & 10 & $<0.001$ & 0.63 \\
NN & $0.1332 \pm 0.011$ & $0.5926 \pm 0.058$ & 37 & $<0.001$ & 0.60 \\
CK & $0.1651 \pm 0.010$ & $0.3893 \pm 0.055$ & 20 & $<0.001$ & 0.54 \\
\hline
\end{tabular}

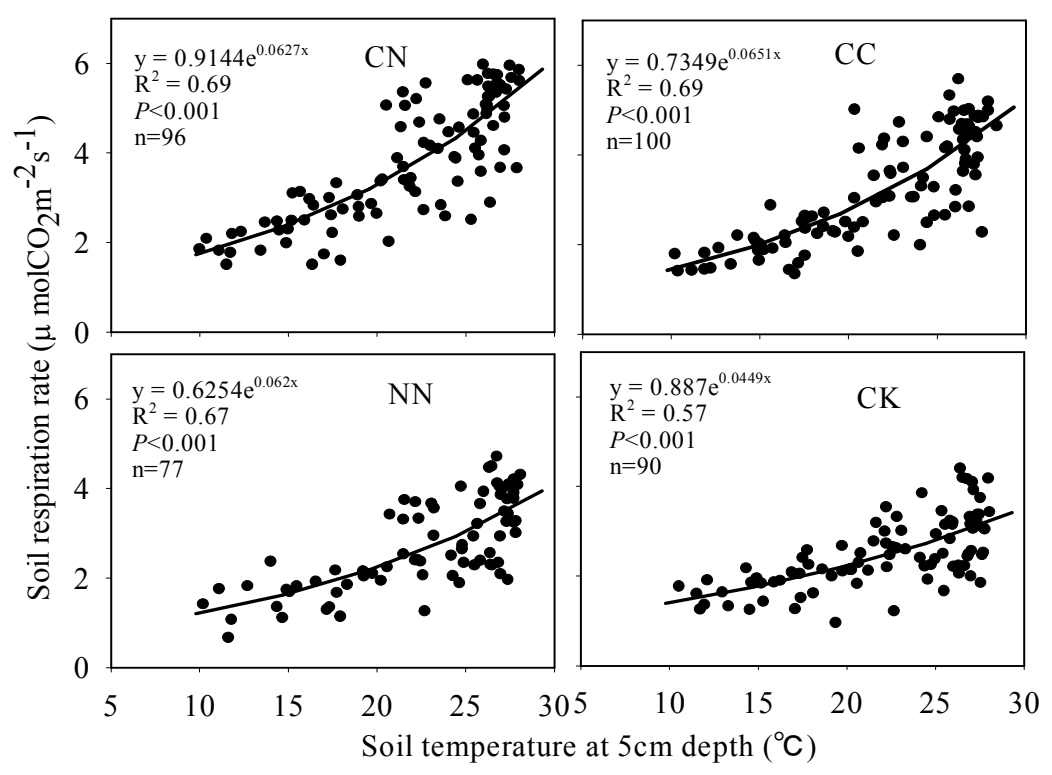

Fig. 2. Relationships between soil respiration rate and soil temperature at $5 \mathrm{~cm}$ depth when soil moisture was larger than $15 \%$ under different $\mathrm{CO}_{2}$ and $\mathrm{N}$ treatments. Each datum in panels $\mathrm{CN}$ and $\mathrm{CC}$ is the mean of three replications. Each datum in panels $\mathrm{NN}$ and $\mathrm{CK}$ is the mean of two replications. The treatments are: $\mathrm{CK}=$ control, $\mathrm{NN}=$ high $\mathrm{N}, \mathrm{CC}=$ elevated $\mathrm{CO}_{2}, \mathrm{CN}=$ elevated $\mathrm{CO}_{2}+$ high $\mathrm{N}$.

root biomass was $1.43,1.29,1.17$ and $0.91 \mathrm{~kg} \mathrm{~m}^{-2}$ in the $\mathrm{CN}, \mathrm{CC}, \mathrm{NN}$ and CK treatment in January 2008, respectively (Fig. 4). Higher SOM was observed only in the CN treatment $(p<0.05)$. There was no significant difference of SOM among the CC, NN and CK chambers $(p>0.05)$. Mean SOM was $2.68,2.17,2.41$ and $2.21 \%$, respectively in the CN, CC, NN and CK treatment in November 2008 (Fig. 4).

\section{Discussion}

\subsection{Effect of soil temperature and moisture on the seasonality of soil respiration}

Soil respiration in all treatments showed strong seasonal patterns with higher value observed in the wet season (AprilSeptember) compared to the dry season (October-March) (Fig. 1). This is consistent with other results reported in 


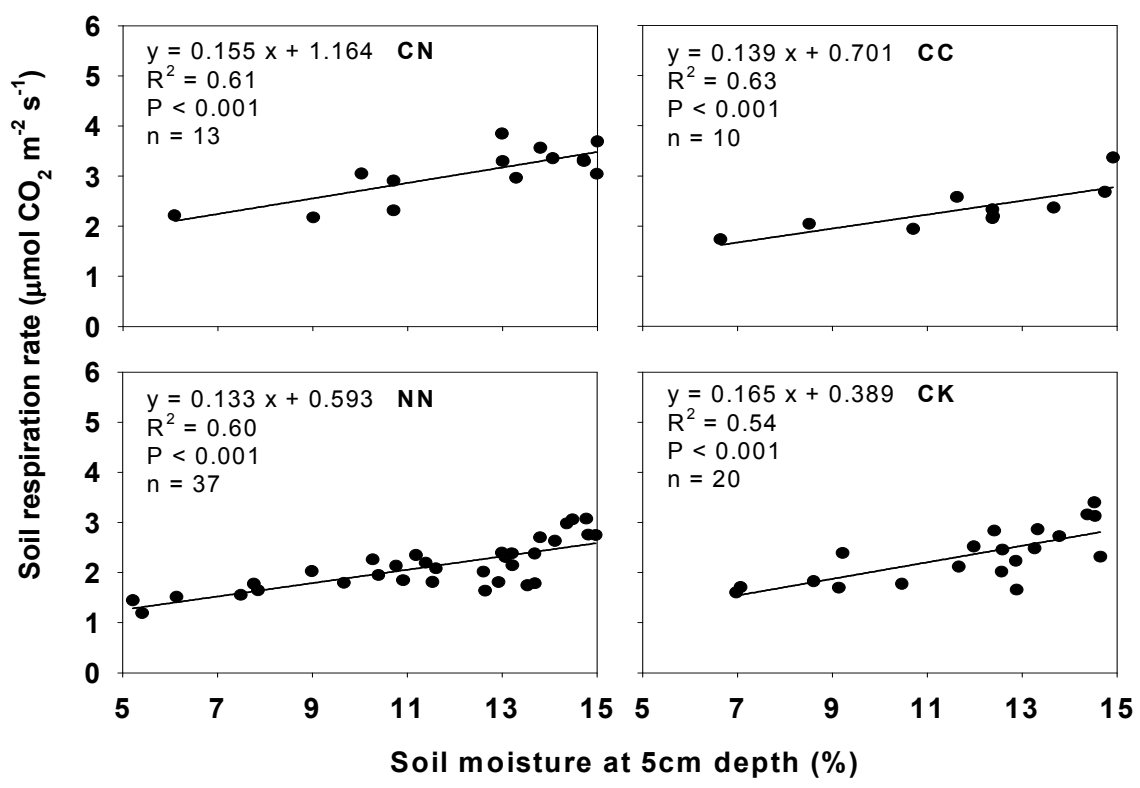

Fig. 3. Relationships between soil respiration rate and soil moisture of the top $5 \mathrm{~cm}$ soil layer (below $15 \%$ ) under different $\mathrm{CO}_{2}$ and $\mathrm{N}$ treatments. Each datum in panels $\mathrm{CN}$ and $\mathrm{CC}$ is the mean of three replications. Each datum in panels $\mathrm{NN}$ and $\mathrm{CK}$ is the mean of two replications. The treatments are: $\mathrm{CK}=$ control, $\mathrm{NN}=$ high $\mathrm{N}, \mathrm{CC}=$ elevated $\mathrm{CO}_{2}, \mathrm{CN}=$ elevated $\mathrm{CO}_{2}+$ high $\mathrm{N}$.

subtropical forests in China (Tang et al., 2006; Zhang et al., 2006; Mo et al., 2007, 2008). This area is characterized by a typical subtropical monsoon climate, where nearly $80 \%$ of annual precipitation falls in the wet season (April to September). Besides, air temperature in the wet season is significantly higher than that in the dry season. Therefore, high plant growth and soil microbial activity in the wet season can stimulate greater soil respiration rate. Positive exponential relationships between soil respiration and soil temperature, as well as positive linear relationships between soil respiration and soil moisture have been found in some warm and moist forests (Sotta et al., 2004; Cleveland and Townsend, 2006; Tang et al., 2006; Zhang et al., 2006; Mo et al., 2007, 2008). In our study, significant exponential relationships between soil respiration rates and soil temperatures were developed when soil moisture was higher than $15 \%$ (Fig. 2). We found that soil respiration linearly increased with soil moisture when soil moisture was below 15\% (Fig. 3). A similar result was reported by Mo et al. (2008) in a mature tropical forest in southern China. Inclan et al. (2007) believed soil moisture effects on soil respiration might occur below a certain threshold varying with soil texture (Dilustro et al., 2005). Our result suggested that soil moisture may play a more important role in soil respiration rate as the soil becomes drier.

\subsection{Temperature sensitivity of soil respiration}

The temperature sensitivity $\left(Q_{10}\right)$ of soil respiration was significantly higher in the $\mathrm{CN}, \mathrm{CC}$ and $\mathrm{NN}$ treatments when compared to the CK chambers (Table 4 and Fig. 2), suggesting that elevated $\left[\mathrm{CO}_{2}\right]$ and $\mathrm{N}$ would increase temperature sensitivity. This is probably because the $\mathrm{CN}, \mathrm{CC}$ and $\mathrm{NN}$ treatments increased the allocation of carbon to the roots. Higher SOM was also observed in the CN treatment. Soil respiration is thought to be controlled primarily by temperature (Lloyd and Taylor, 1994). This is based on the assumption that enzymatic rates control soil physiological processes to a greater extent than resource supply rates (Skopp et al., 1990; Craine et al., 1998). Zheng et al. (2009) also reported that $Q_{10}$ of soil respiration was primarily determined by soil temperature during measurement periods, soil organic carbon (SOC) content, and ecosystem type. So the respiratory substrate availability plays a crucial role in the response of soil respiration to soil temperature (Liu et al., 2006). When substrate supply is low, the temperature sensitivity of soil respiration is low. Otherwise, increased substrate supply can elevate the temperature sensitivity of soil respiration. Therefore, these additional substrates of root biomass and SOM (Fig. 4) for autotrophic and heterotrophic respiration in our study could result in high temperature sensitivity (Dhillion et al., 1996; Lin et al., 2001; Pendall et al., 2004).

\subsection{Effect of elevated $\left[\mathrm{CO}_{2}\right]$ on soil respiration}

Many studies indicated that elevated $\left[\mathrm{CO}_{2}\right]$ increased soil respiration significantly (Lin et al., 2001; King et al., 2004; Astrid et al., 2004; Bernhardt et al., 2006; Pregitzer et al., 2008). Our results also demonstrated that elevated $\mathrm{CO}_{2}$ resulted in a considerable increase of carbon release (about $29 \%$ on average) from the forest floor. The increase was comparable to an open-top chamber study in eastern Finland which reported about a 30\% increase (Sini et al., 2004). 
Table 5. Aannual or semiannual soil respiration $(R)$ and its $\%$ increased for each year of the experiment (mean \pm standard deviations). Standard deviation within each treatment showed the dispersion among open-top chambers employed for each treatment. $n=3$ for the $\mathrm{CN}$ and CC treatments, $n=2$ for the NN treatment and CK. $R$ within a row with different lowercase letter have significant treatment differences at $\alpha=0.05$ level. The treatments are: $\mathrm{CK}=$ control, $\mathrm{NN}=$ high $\mathrm{N}, \mathrm{CC}=$ elevated $\mathrm{CO}_{2}, \mathrm{CN}=$ elevated $\mathrm{CO}_{2}+$ high $\mathrm{N} . \%$ increased $=100$ $((R$ of each treatment $-R$ of the $\mathrm{CK}) / R$ of the $\mathrm{CK}) \%$ (in the same year). Unit: $\mathrm{kg} \mathrm{CO}_{2} \mathrm{~m}^{-2} 6$-months ${ }^{-1}$ for $R$ in the latter half of 2006 ; $\mathrm{kg} \mathrm{CO}_{2} \mathrm{~m}^{-2} \mathrm{yr}^{-1}$ for $R$ in 2007 and 2008 .

\begin{tabular}{cccccccc}
\hline \multirow{2}{*}{ Year* } & \multicolumn{2}{c}{ CN } & \multicolumn{2}{c}{ CC } & \multicolumn{2}{c}{ NN } & \multicolumn{2}{c}{ CK } \\
& $R$ & $\%$ increased & $R$ & $\%$ increased & $R$ & $\%$ increased & $R$ \\
\hline 2006 & $2.72 \pm 0.9 \mathrm{a}$ & 49.24 & $2.22 \pm 0.12 \mathrm{~b}$ & 27.24 & $1.97 \pm 0.10 \mathrm{c}$ & 8.17 & $1.83 \pm 0.03 \mathrm{~d}$ \\
2007 & $5.16 \pm 0.10 \mathrm{a}$ & 49.57 & $4.43 \pm 0.18 \mathrm{~b}$ & 28.41 & $3.53 \pm 0.10 \mathrm{c}$ & 2.32 & $3.45 \pm 0.07 \mathrm{c}$ \\
2008 & $5.48 \pm 0.12 \mathrm{a}$ & 51.38 & $4.65 \pm 0.06 \mathrm{~b}$ & 28.45 & $3.60 \pm 0.05 \mathrm{c}$ & -0.55 & $3.62 \pm 0.01 \mathrm{c}$ \\
mean & $5.32 \pm 0.09 \mathrm{a}$ & 50.07 & $4.54 \pm 0.10 \mathrm{~b}$ & 28.61 & $3.56 \pm 0.03 \mathrm{c}$ & 0.01 & $3.53 \pm 0.03 \mathrm{c}$ \\
\hline
\end{tabular}

* Because the measurement of soil respiration begun in 26 June 2006, we only estimate semiannual soil respiration from July to December in 2006 and estimate the mean value of all year from 2007 to 2008.

However, it was higher than the Duke Forest Free Air $\mathrm{CO}_{2}$ Enrichment (FACE) Experiment (about $16 \%$ on average) (Bernhardt et al., 2006) and the FACE Experiment of the Federal Agricultural Research Centre (about $17 \%$ on average) (Astrid et al., 2004). The increased soil respiration in the CC chambers may be due to the following two reasons. Firstly, increased soil moisture under elevated $\left[\mathrm{CO}_{2}\right]$ may increase SOM decomposition rate and stimulate soil microbial respiration. Many studies showed that $\mathrm{CO}_{2}$ enrichment increased soil moisture (Amthor, 2001; Bunce 2004). Higher soil moisture in the $\mathrm{CC}$ treatment was revealed at our study sites (Tables 2 and 3), which would stimulate soil microbial processes (Niklaus et al., 1998) by improving litter decomposition and nutrient mineralization. Secondly, increased root biomass may increase root respiration and rhizosphere microbial respiration. Most studies showed that elevated $\left[\mathrm{CO}_{2}\right]$ increased fine root biomass and in most cases higher fine turnover resulted in higher $\mathrm{C}$ input into soil via root necromass (Edwards and Norby, 1999; Norby and Luo, 2004; Lukac et al., 2009). In our study, elevated $\left[\mathrm{CO}_{2}\right]$ increased root biomass (Fig. 4) that was also accompanied by increased $\mathrm{CO}_{2}$ loss from the soils.

By analyzing each treatment's annual or semiannual soil respiration in the latter half of 2006, 2007 and 2008, we observed that the stimulatory effect of elevated $\left[\mathrm{CO}_{2}\right]$ on soil respiration was maintained throughout the experimental period (Table 5). This is not consistent with some other reports which showed that soil respiration gradually declined over time because of the $\mathrm{N}$ limitation (e.g., Bernhardt et al., 2006). Increases in photosynthetic carbon gain under elevated $\left[\mathrm{CO}_{2}\right]$ need to be matched by increases in nutrient supply and/or increases in plant nutrient-use efficiency, otherwise the effect of $\mathrm{CO}_{2}$ enrichment on plant growth may weaken due to N-limitation (Norby et al., 1986; Murray et al., 2000). At our study area, the rapid expansion of industrial and agricultural activities in subtropical regions has resulted in high atmospheric $\mathrm{N}$ deposition $\left(\mathrm{NH}_{4}^{+}-\mathrm{N}, \mathrm{NO}_{3}^{-}\right.$-
$\mathrm{N})$ in forests of southern China (30-73 $\mathrm{kg} \mathrm{N} \mathrm{ha}^{-1} \mathrm{yr}^{-1}$ ) (Ma, 1989; Ren et al., 2000; Xu et al., 2001). It seems that plant growth is not limited by $\mathrm{N}$ under elevated $\left[\mathrm{CO}_{2}\right]$ in the long term. This may be the reason that the stimulatory effect of elevated $\left[\mathrm{CO}_{2}\right]$ on soil respiration might be sustained over time, at least during the current experimental period.

\subsection{Effect of $\mathrm{N}$ addition on soil respiration}

Some other studies showed that soil respiration would be suppressed under $\mathrm{N}$ addition (Boxman et al., 1998; Mo et al., 2008). However, the repeated measures ANOVA in our study showed that a positive effect on soil respiration existed in the NN treatment, which may primarily owe to $\mathrm{N}$ addition stimulating soil respiration rate at the very start of the experiment. This is similar to the pattern observed by Bowden et al. (2004) that $\mathrm{N}$ addition could increase soil respiration significantly in the first 2 years. The response of soil respiration to elevated $\mathrm{N}$ deposition was influenced by the degree of initial soil nutrient status (Mo et al., 2007). We also believed that young seedlings used in this study grew quickly and required more soil $\mathrm{N}$, which would lead to a transitory and slight $\mathrm{N}$ limitation at our study sites. Increased aboveground biomass and increased root biomass (Fig. 4) was obtained in the $\mathrm{N}$ treatment (Duan et al., 2009). As Bowden et al. (2004) suggested, it is likely that added soil carbon from aboveand below-ground litter would stimulate heterotrophic respiration, and greater root biomass enhanced autotrophic respiration under $\mathrm{N}$ addition. Lu et al. (1998) also reported that the root respiration rate for seedlings grown at $50 \mathrm{mg} \mathrm{L}^{-1} \mathrm{~N}$ concentration due to increased root biomass was significantly higher than for seedlings grown at $10 \mathrm{mg} \mathrm{L}^{-1} \mathrm{~N}$.

By analyzing each treatment's annual or semiannual soil respiration in the latter half of 2006, 2007 and 2008, we observed that the positive effect of $\mathrm{N}$ addition treatment existed in the year 2006 and it had been weakened over time. Aber et al. (1989) reported that $\mathrm{N}$ additions would initially stimulate 

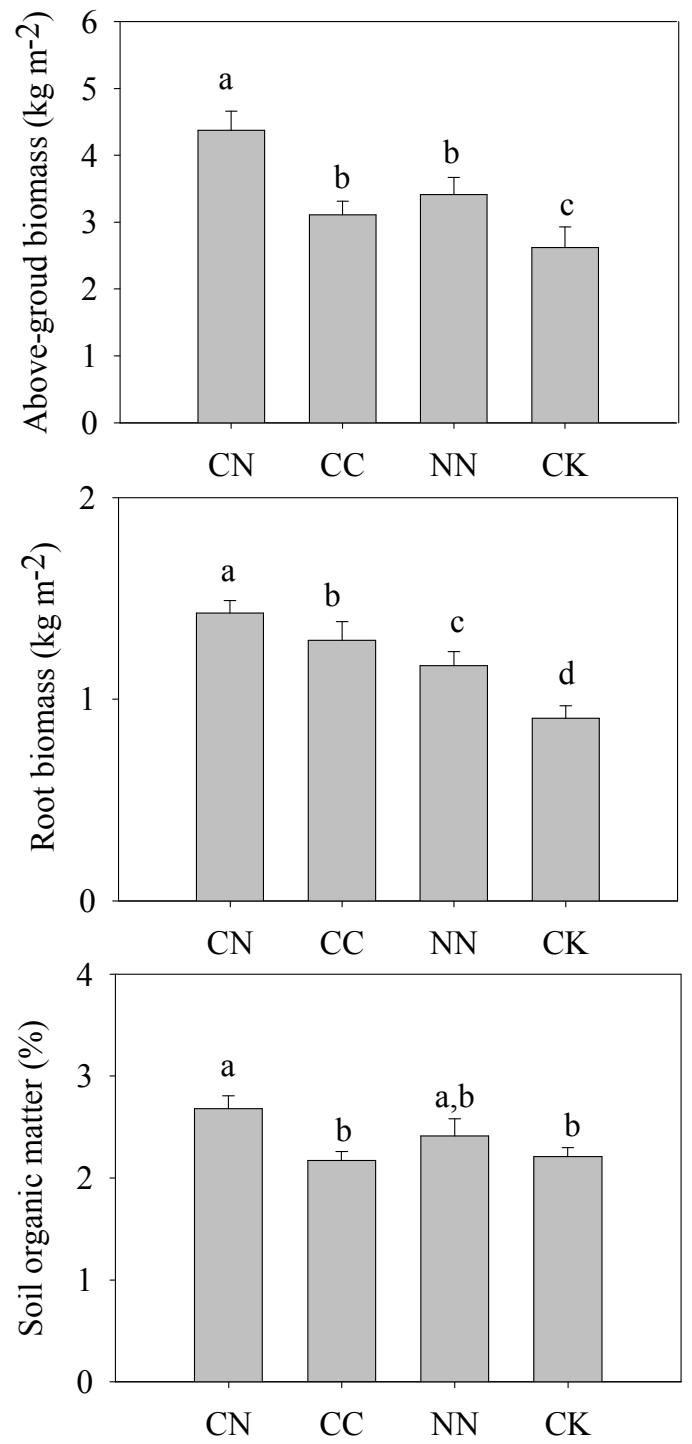

Fig. 4. Above-ground biomass and root biomass in January 2008, and soil organic matter in November 2008 under different $\mathrm{CO}_{2}$ and $\mathrm{N}$ treatments. Error bars are standard deviations, which showed the dispersion among open-top chambers employed for each treatment. $n=3$ for the $\mathrm{CN}$ and $\mathrm{CC}$ treatments, $n=2$ for the NN treatment and CK. Different letters denote significant difference between treatments. Significant level is set at $\alpha=0.05$. The treatments are: $\mathrm{CK}$ $=$ control, $\mathrm{NN}=$ high $\mathrm{N}, \mathrm{CC}=$ elevated $\mathrm{CO}_{2}, \mathrm{CN}=$ elevated $\mathrm{CO}_{2}+$ high $\mathrm{N}$.

soil microbial activity, but would lead to a carbon limitation state after microbial demand for $\mathrm{N}$ was satisfied over time. In addition, plant growth would become slow over time and needed to assimilate less $\mathrm{N}$ from soil. Meanwhile, with larger doses of $\mathrm{N}$ readily available for uptake, energetic costs of $\mathrm{N}$ assimilation may have been reduced. Since a large fraction of root respiration is allocated to $\mathrm{N}$ assimilation (Bloom et al., 1992), root activity and autotrophic respiration would weaken (Bowden et al., 2004). Here we have not direct data to prove that the root activity and soil microbial activity were weakening under $\mathrm{N}$ addition in our study. However, soil microbial activity was closely related to soil moisture (Kucera et al., 1971). In our study, $\mathrm{N}$ addition significantly decreased soil moisture (Table 3), which might be due to the increased plant growth (Duan et al., 2009) and the increased diffusive conductance and stomatal conductance of the leaves in the NN chambers (Li et al., 2004; Duan, H. L., unpublished data). Since there was a significant positive linear relationship between soil respiration rates and soil moisture when soil moisture was below $15 \%$ (Fig. 3), soil respiration would gradually be suppressed with drier soil under $\mathrm{N}$ addition (Table 2). Especially in the dry season, for which mean soil moisture was below $15 \%$, mean soil respiration rate in the $\mathrm{NN}$ chambers had a little decrease compared to the CK chambers (Table 3). This gradually weakening trend suggested that the responses of soil respiration might reverse in the future under the continued $\mathrm{N}$ addition at our study sites.

\subsection{Interactive effect of elevated $\left[\mathrm{CO}_{2}\right]$ and $\mathrm{N}$ addition on soil respiration}

Increasing atmospheric $\mathrm{CO}_{2}$ and $\mathrm{N}$ deposition are two primary and concurrent changes in subtropical China. Elevated $\left[\mathrm{CO}_{2}\right]$ could maintain increasing plant growth under $\mathrm{N}$ addition (Finzi et al., 2002). Elevated $\left[\mathrm{CO}_{2}\right]$ and $\mathrm{N}$ addition affected each other in stimulating plant growth (Hungate et al., 2003; Luo et al., 2004; de Graaff et al., 2006), which could result in potential and complex interactive effects on soil respiration. Allen and Schlesinger (2004) reported that $\mathrm{N}$ addition could increase soil respiration in FACE soil cores due to accelerated litter decomposition. However, experimental results in the FACE prototype plot (Oren et al., 2001) showed that adding $\mathrm{N}$ fertilizer led to reduced soil respiration response to elevated $\left[\mathrm{CO}_{2}\right]$ (Butnor et al., 2003). In addition, Astrid et al. (2004) found that different levels of $\mathrm{N}$ fertilization generally had no effect on soil respiration in ambient and elevated $\left[\mathrm{CO}_{2}\right]$ rings, because $\mathrm{N}$ seemed not to be a controlling factor in their study sites.

At our studies sites, although there was high ambient $\mathrm{N}$ deposition, a significant interactive effect between elevated $\left[\mathrm{CO}_{2}\right]$ and $\mathrm{N}$ addition $(F=7.24, p=0.006)$ was found, and the combined effect of them increased soil respiration by $50 \%$ compared to that in the CK chambers (Table 5). This may be because young seedlings used in this study grew quickly and required more soil $\mathrm{N}$. A positive effect on soil respiration was revealed in the $\mathrm{N}$ treatment (Tables 2 and 3), which indicated a transitory and slight $\mathrm{N}$ limitation. This $\mathrm{N}$ limitation would be intensified and prolonged to a certain extent under elevated $\left[\mathrm{CO}_{2}\right]$, because $\left[\mathrm{CO}_{2}\right]$ led to greater photosynthetic assimilation rates, and required more $\mathrm{N}$ from soil for plant growth. As a result, the greatest above-ground biomass, root biomass and SOM were also revealed in the $\mathrm{CN}$ treatment at our study sites (Fig. 4). In several OTC 
studies with $\mathrm{CO}_{2}$ and $\mathrm{N}$ manipulations, poplar seedlings and saplings $(\approx 1-5$ years old) had greater plant growth stimulation by elevated $\left[\mathrm{CO}_{2}\right]$ at high rather than at low $\mathrm{N}$ supply after two years in Michigan (Zak et al., 2000) and Italy (Liberloo et al., 2005) and three years in Iceland (Sigurdson et al., 2001). Higher root biomass could increase root respiration and rhizosphere microbial respiration. Higher SOM would provide additional carbon supplies to decomposers (Zak et al., 2000), which would stimulate heterotrophic respiration. This might be the reason that the response of soil respiration in young subtropical forest ecosystems to elevated $\left[\mathrm{CO}_{2}\right]$ under high $\mathrm{N}$ deposition was much stronger than under low $\mathrm{N}$ deposition.

In addition, varied soil moisture due to $\mathrm{CO}_{2}$ treatment may affect soil respiration response to $\mathrm{N}$ addition. Soil microbial processes such as litter decomposition and nutrient mineralization were stimulated by soil moisture (Niklaus et al., 1998). At our study, soil respiration was gradually suppressed when soil moisture was below $15 \%$ (Table 2). We found that soil moisture was significantly reduced by $\mathrm{N}$ addition alone (Tables 2 and 3), particularly in dry season (all below 15\%), which also led to reduced soil respiration. But this decreased soil moisture was offset by elevated $\left[\mathrm{CO}_{2}\right]$. As a result, soil moisture in the $\mathrm{CN}$ treatment was significantly higher than that in the NN treatment (Table 3). Thus, the effect of $\mathrm{N}$ on soil respiration was enhanced by $\mathrm{CO}_{2}$ treatment, further indicating a strong interactive effect of these two factors on soil respiration.

\section{Conclusions}

By measuring soil respiration in open-top chambers with young subtropical trees under different $\mathrm{CO}_{2}$ and $\mathrm{N}$ treatments, we estimated main and interactive effects of $\mathrm{CO}_{2}$ and $\mathrm{N}$ on soil respiration. Soil respiration displayed strong seasonal patterns, with higher values observed in the wet season and lower values in the dry season in all treatments, which were primarily driven by soil temperature and soil moisture. Both $\mathrm{CO}_{2}$ and $\mathrm{N}$ treatments significantly affected soil respiration, and there were significant interactions between elevated $\left[\mathrm{CO}_{2}\right]$ and $\mathrm{N}$ addition. Soil respiration was the highest in the chambers exposed to elevated $\left[\mathrm{CO}_{2}\right]$ and high $\mathrm{N}$ deposition $(\mathrm{CN})$, followed by the chambers exposed to elevated $\left[\mathrm{CO}_{2}\right]$ and ambient $\mathrm{N}$ deposition $(\mathrm{CC})$, ambient $\left[\mathrm{CO}_{2}\right]$ and high $\mathrm{N}$ deposition $(\mathrm{NN})$, and ambient $\left[\mathrm{CO}_{2}\right]$ and ambient $\mathrm{N}$ deposition ( $\mathrm{CK}$ as a control). However, the stimulatory effect of elevated $\left[\mathrm{CO}_{2}\right]$ on soil respiration was sustained over time because of a high ambient $\mathrm{N}$ deposition in subtropical China, even under no $\mathrm{N}$ addition. In addition, we found the positive effect of $\mathrm{N}$ addition alone had been weakened over time. These two different trends of $\mathrm{CO}_{2}$ and $\mathrm{N}$ on soil respiration could lead to a potential and more complex interactive effect of elevated $\left[\mathrm{CO}_{2}\right]$ and $\mathrm{N}$ addition on soil respiration in the future. Studies on source components of soil respiration and multiple aspects of soil carbon cycling are needed in long-term experiment under different $\mathrm{CO}_{2}$ and $\mathrm{N}$ treatments.

Acknowledgements. This work was jointly funded by National Science Fund for Distinguished Young Scholars (30725006), National Basic Research Program of China (No.2009CB421101), National Natural Science Foundation of China (40730102, 30700112, 30721140307), Guangdong Provincial Natural Science Foundation of China (8351065005000001, 7006918) and Dinghushan Forest Ecosystem Research Station. We are grateful to Dafeng Hui at Tennessee State University, Nashville, TN, USA, for his valuable comments, and Jennifer Cartwright and Sara Jabeen who provide English improvements.

Edited by: T. Hirano

\section{References}

Aber, J. D., Nadelhoffer, K. J., Steudler, P., Melillo, J. M.: Nitrogen saturation in northern forest ecosystems, BioScience, 39, 378386, 1989.

Allard, V., Robin, C., Newton, P. C. D., Lieffering, M., and Soussana, J. F.: Short and long-term effects of elevated $\mathrm{CO}_{2}$ on Lolium perenne rhizodeposition and its consequences on soil organic matter turnover and plant $\mathrm{N}$ yield, Soil Biology and Biochemistry, 38(6), 1178-1187, 2006.

Allen, A. S. and Schlesinger, W. H.: Nutrient limitations to soil microbial biomass and activity in loblolly pine forests, Soil Biol. Biochem., 36, 581-589, 2004.

Amthor, J. S.: Effects of atmospheric $\mathrm{CO}_{2}$ concentration on wheat yield: review of results from experiments using various approaches to control $\mathrm{CO}_{2}$ concentration, Field Crop. Res., 73, 2134, 2001.

Anderson, T. H. and Joergensen, G. R.: Relationship between SIR and FE estimates of microbial biomass $\mathrm{C}$ in deciduous forest soil at different PH, Soil Biol. Biochem., 29(7), 1033-1042, 1997.

Astrid, R. B., Giesemann, A., Anderson, T. H., Weigel, H. J., and Buchmann, N.: Soil respiration under elevated $\mathrm{CO}_{2}$ and its partitioning into recently assimilated and older carbon sources, Plant Soil, 262, 85-94, 2004.

Bernhardt, E. S., Barber, J. J., Pippen, J. S., Taneva, L., Andrews, J. A., and Schlesinger, W. H.: Long-term effects of Free Air $\mathrm{CO}_{2}$ Enrichment (FACE) on soil respiration, Biogeochemistry, 77, 91-116, 2006.

Boxman, A. W., Blanck, K., Brandrud, T. E., Emmett, B. A., Gundersen, P., Hogervorst, R. F., Kjonaas, O. J., Person, H., and Timmermann, V.: Vegetation and soil biota response to experimentally-changed nitrogen inputs in coniferous forest ecosystems of the NITREX project, Forest Ecol. Manag., 101, 65-79, 1998.

Bowden, R. D., Davidson, E., Savage, K., Arabia, C., and Steudler, P.: Chronic nitrogen additions reduce total soil respiration and microbial respiration in temperate forest soils at the Harvard Forest, Forest Ecol. Manag., 196, 43-56, 2004.

Bowden, R. D., Rullo, G., and Sevens, G. R.: Soil fluxes of carbon dioxide, nitrous oxide, and methane at a productive temperate deciduous forest, J. Environ. Qual., 29, 268-276, 2000. 
Buchmann, N.: Biotic and abiotic factors controlling soil respiration rates in Picea abies stands, Soil Biology and Biochemistry, 32, 1625-1635, 2000.

Bunce, J. A.: Carbon dioxide effects on stomatal responses to the environment and water use by crops under field conditions, Oecologia, 140, 1-10, 2004.

Burton, A. J., Pregitzer, K., Crawford, J. N., Zogg, G. P., and Zak, D. R.: Simulated chronic $\mathrm{NO}_{3}^{-}$deposition reduces soil respiration in northern hardwood forests, Glob. Change Biol., 10, 10801091, 2004.

Butnor, J. R., Johnsen, K. H., Oren, R., and Katul, G. G.: Reduction of forest floor respiration by fertilization on both carbon dioxideenriched and reference 17-year-old loblolly pine stands, Glob. Change Biol., 9, 849-861, 2003.

Chen, X. Y. and Mulder, J.: Indicators for nitrogen status and leaching in subtropical forest ecosystems, South China, Biogeochemistry, 82, 165-180, 2007.

Cleveland, C. C. and Townsend, A. R.: Nutrient additions to a tropical rain forest drive substantial soil carbon dioxide losses to the atmosphere, Proceedings of National Academy of Sciences, 103, 10316-10321, 2006.

Contrasting effects of elevated $\mathrm{CO}_{2}$ on old and new soil carbon pools, Soil Biology and Biochemistry, 33, 365-373, 2001.

Cox, P. M., Betts, R. A., Jones, C. D., Spall, S. A., and Totterdell, I. J.: Acceleration of global warming due to carbon-cycle feedbacks in a coupled climate model, Nature, 408, 184-187, 2000.

Craine, J. M., Wedin, D. A., and Chapin, F. S.: Predominance of ecophysiogical controls on soil $\mathrm{CO}_{2}$ flux in a Minnesota grassland, Plant Soil, 207, 77-86, 1998.

Cramer, W., Bondeau, A., lan Woodward, F., Prentice, C., Betts, A., Brovkin, V., Cox, P. M., Fisher, V., Foley, J. A., Friend, A. D., Kucharik, C., Lomas, M. R., Ramankutty, N., Sitch, S., Smith, B., White, A., and Mollong, C. Y.: Global response of terrestrial ecosystem structure and function to $\mathrm{CO}_{2}$ and climate change: results from six dynamic global vegetation models, Glob. Change Biol., 7(4), 357-373, 2001.

de Graaff, M., van Groenigen, K., Six, J., and van Kessel, C.: Interactions between plant growth and soil nutrient cycling under elevated $\mathrm{CO}_{2}$ : a meta-analysis, Glob. Change Biol., 12, 20772091, 2006.

Dhillion, S. C., Roy, J., and Abrams, M.: Assessing the impact of elevated $\mathrm{CO}_{2}$ on soil microbial activity in a Mediterranean ecosystem, Plant Soil, 187, 333-342, 1996.

Duan, H. L., Liu, J. X., Deng, Q., Chen, X. M., and Zhang, D. $\mathrm{Q}$.: Effects of elevated $\mathrm{CO}_{2}$ and $\mathrm{N}$ deposition on plant biomass accumulation and allocation in subtropical forest ecosystems: a mesocosm study, Chinese Journal of Plant Ecology, (in Chinese with English abstract), 33(3), 572-579, 2009.

Edwards, N. T. and Norby, R. J.: Below-ground respiratory responses of sugar maple and red maple saplings to atmospheric $\mathrm{CO}_{2}$ enrichment and elevated air temperature, Plant Soil, 206, 85-97, 1999.

Finzi, A. C., DeLucia, E. H., Hamilton, J. G., Richter, D. D., and Schlesinger, W. H.: The nitrogen budget of a pine forest under Free Air $\mathrm{CO}_{2}$ Enrichment, Oecologia, 132(4), 567-578, 2002.
Galloway, J. N., Dentener, F. J., and Capone, D. G.: Nitrogen cycles: past, present and future, Biogeochemistry, 70, 153-226, 2004.

Huber, C., Weis, W., Baumgarten, M., and Gottlein, A.: Spatial and temporal variation of seepage water chemistry after femel and small scale clear-cutting in a N-saturated Norway spure stand, Plant Soil, 267, 23-40, 2004.

Hungate, B. A., Dukes, J. S., Shaw, M. R., and Luo, Y. Q., Field, C. B.: Nitrogen and climate change, Science, 302, 1512-1513, 2003.

Inclan, R., de la Torre, D., Benito, M., and Rubio, A.: Soil $\mathrm{CO}_{2}$ efflux in a mixed pine-oak forest in Valsain (central Spain), The Scientific World Journal, 7, 166-174, 2007.

Intergovernmental Panel on Climate Change (IPCC).: Land Use, Land Use Change, and Forestry, Cambridge University Press, Cambridge, 1-51, 2001.

Kemmitt, S. J., Wright, D., Goulding, and K. W. T.: PH regulation of carbon and nitrogen dynamics in two agricultural soil, Soil Biology and Biochemistry, 38(5), 898-911, 2006.

King, J. S., Hanson, P. J., Bernhardt, E., Deangeli, P., Norby, R. J., and Pregitzer, K. S.: A multiyear synthesis of soil respiration responses to elevated atmospheric $\mathrm{CO}_{2}$ from four forest FACE experiments, Glob. Change Biol., 10, 1027-1042, 2004.

Kucera, C. L. and Kirkham, D. R.: Soil respiration studies in tallgrass prairie in Missouri, Ecology, 52, 912-915, 1971.

Li, D. J., Mo, J. M., Fang, Y. T., Cai, X. A., Xue, J. H., and Xu, G. L.: Effects of simulated nitrogen deposition on growth and photosynthesis of Schima superba, Castanopsis chinensis and Cryptocarya concinna seedlings, Acta Ecologica Sinica, (in Chinese with English abstract), 24(5), 876-882, 2004.

Li, Y. L., Otieno, D., Owen, Q., Tenhunen, J., Zhang, Y., Lin, Y. B., and Rao X. Q.: Temporal variability in soil $\mathrm{CO}_{2}$ emission in an Orchard forest ecosystem in lower subtropical China, Pedosphere, 18, 273-283, 2008.

Liberloo, M., Dillen, S.Y., Calfapietra, C., Marinari, S., Luo, Z.B., et al.: Elevated $\mathrm{CO} 2$ concentration, fertilization and their interaction: growth stimulation in a short-rotation poplar coppice (EUROFACE), Tree Physiology, 25, 179-89, 2005.

Lin, G., Rygiewicz, P. T., Ehleringer, J. R., Johnson, M. G., and Tingey, D. T.: Time-dependent responses of $\mathrm{CO}_{2}$ efflux components to elevated atmospheric $\mathrm{CO}_{2}$ and temperature in experimental forest mesocosms, Plant Soil, 229, 259-270, 2001.

Liu, H. S., Li, L. H., Han, X. G., Huang, J. H., Sun, J. X., and Huang, H. Y.: Respiratory substrate availability plays a crucial role in the response of soil respiration to environmental factors, Appl. Soil Ecol., 32, 284-292, 2006.

Liu, J. X., Zhang, D. Q., Zhou, G. Y., Benjamin, F. V., Deng, Q., and Wang, C. L.: $\mathrm{CO}_{2}$ enrichment increases cation and anion loss in leaching water of model forest ecosystems in southern China, Biogeoscience, 5, 1783-1795, 2008.

Lloyd, J. and Taylor, J. A.: On the temperature dependence of soil respiration, Funct. Ecol., 8, 315-323, 1994.

Lu, S.J., Mattson, K.G., Zaerr, J.B., et al.: Root respiration of Douglas-fir seedlings: Effects of N concentration, Soil Biology and Biochemistry, 30(3), 331-336, 1998. 
Luo, Y. Q., Jacson, R. B., Field, C. B., and Mooney, H. A.: Elevated $\mathrm{CO}_{2}$ increases below ground respiration in California grasslands, Oecologia, 108, 130-137, 1996.

Luo, Y. Q., Su, B., Currie, W. S., Dukes, J. E., Finzi, A., Hartwig, U., Hungate, B., Mc Murtrie, R. E., Oren, R., Parton, W. J., Pataki, D. E., Rebecca Shaw, M., Zak, D. R., and Field, C. B.: Progressive nitrogen limitation of ecosystem responses to rising atmospheric carbon dioxide, BioScience, 54(8), 731-739, 2004.

Ma, X. H.: Effects of rainfall on the nutrient cycling in manmade forests of Cunninghamia lanceolata and Pinus massoniana, Acta Ecologica Sinica, (in Chinese with English abstract), 9, 15-20, 1989.

Lukac, M., Lagomarsino, A., Cristine Moscatelli, M., de Angelis, M., Prancesca Cotrufo, M., and Godbold, D. L.: Forest soil carbon cycle under elevated $\mathrm{CO}_{2}$-a case of increased throughput? Forestry, 82(1), 75-86, 2009.

Micks, P., Aber, J. D., Boone, R. D., and Davidson, E. A.: Shortterm soil respiration and nitrogen immobilization response to nitrogen applications in control and nitrogen-enriched temperate forests, Forest Ecol. Manag., 196, 57-70, 2004.

Mo, J. M., Brown, S., Xue, J. H., Fang, Y. T., and Li, Z. A.: Response of litter decomposition to simulated $\mathrm{N}$ deposition in disturbed, rehabilitated and mature forests in subtropical China, Plant Soil, 282, 135-151, 2006.

Mo, J. M., Zhang, W., Zhu, W. X., Fang, Y. T., Li, D. J., and Zhao, P.: Response of soil respiration to simulated $\mathrm{N}$ deposition in a disturbed and a rehabilitated tropical forest in southern China, Plant Soil, 296, 125-135, 2007.

Mo, J. M., Zhang, W., Zhu, W. X., Gundersen, P., Fang, Y. T., Li, D. J., and Wang, H.: Nitrogen addition reduces soil respiration in a mature tropical forest in southern China, Glob. Change Biol., 14, 403-412, 2008.

Moyano, F. E., Kutsch, W. L., and Rebmann, C.: Soil respiration fluxes in relation to photosynthetic activity in broad-leaf and needle-leaf forest stands, Agr. Forest Meteorol., 148, 135-143, 2008.

Murray, M. B., Smith, R. I., Friend, A., and Jarvis, P. G.: Effect of elevated $\left[\mathrm{CO}_{2}\right]$ and varying nutrient application rates on physiology and biomass accumulation of Sitka spruce (Picea sitchensis), Tree Physiology, 20, 421-434, 2000.

Nelson, D. W. and Sommers, L. E.: Total carbon, organic carbon, and organic matter, 539-580, 1982.

Niklaus, P. A., Spinnler, D., and Kornerb, C.: Soil moisture dynamics of calcareous grassland under elevated $\mathrm{CO}_{2}$, Oecologia, 117 , 201-208, 1998.

Norby, R. J. and Luo, Y. Q.: Evaluating ecosystem responses to rising atmospheric $\mathrm{CO}_{2}$ and global warming in a multi-factor world, New Phytol., 162, 281-293, 2004.

Norby, R. J., O’Neill, E. G., and Luxmoore, R. J.: Effects of atmospheric $\mathrm{CO}_{2}$ enrichment on the growth and mineral nutrition of Quercus alba Seedlings in nutrient-poor soil, Plant Physiol., 82, 83-89, 1986.

Oren, R., Ellsworth, D. S., Johnsen, K. H., Phillips, N., Ewers, B. E., Maier, C., Schafer, K. V. R., McCarthy, H., Hendrey, G., McNulty, S. G., and Katul, G. G.: Soil fertility limits carbon sequestration by forest ecosystems in a $\mathrm{CO}_{2}$-enriched atmosphere, Nature, 411, 469-472, 2001.

Pearson, M., Davies, W. J., and Mansfield, T. A.: Asymmetric responses of adaxial and abaxial stomata to elevated $\mathrm{CO}_{2}$-impacts on the control of gas-exchange by leaves, Plant Cell and Environment, 18(8), 837-843, 1995.

Pendall, E., Bridgham, S., Hanson, P. J., Hungate, B., Kicklighter, D. W., Johnson, D. W., Law, B. E., Luo, Y. Q., Megonigal, J. P., Olsrud, M., Ryan, M. G., Wan, S. Q.: Below-ground process responses to elevated $\mathrm{CO}_{2}$ and temperature: a discussion of observations, measurement methods, and models, New Phytol., 162, 311-322, 2004.

Pregitzer, K. S., Burton, A. J., King, J. S., and Zak, D. R.: Soil respiration, root biomass, and root turnover following long-term exposure of northern forests to elevated atmospheric $\mathrm{CO}_{2}$ and tropospheric $\mathrm{O}_{3}$, New Phytol., 180, 153-161, 2008.

Raich, J. W. and Schlesinger, W. H.: he global carbon dioxide flux in soil respiration and its relationship to vegetation and climate, Tellus, 44B, 81-99, 1992.

Ren, R., Mi, F. J., and Bai, N. B.: A chemometrics analysis on the data of precipitation chemistry of China, Journal of Beijing Polytechnic University, (in Chinese with English abstract), 26, 90-95, 2000.

Saxe, H., Ellsworth, D. S., and Heath, J.: Tansley Review No. 98 Tree and forest functioning in an enriched $\mathrm{CO}_{2}$ atmosphere, New Phytol., 139, 395-436, 1998.

Shaw, M. R., Zavaleta, E. S., and Chiariello, N. R.: Grassland responses to global environmental changes suppressed be y elevated $\mathrm{CO}_{2}$, Science, 298, 1987-1990, 2002.

Sigurdsson, B. D., Thorgeirsson, H., and Linder, S.: Growth and dry-matter partitioning of young Populus trichocarpa in response to carbon dioxide concentration and mineral nutrient availability, Tree Physiology, 21, 941-50, 2001.

Sini, M. N., Jouko, S., and Seppo, K.: Soil $\mathrm{CO}_{2}$ efflux in a boreal pine forest under atmospheric $\mathrm{CO}_{2}$ enrichment and air warming, Glob. Change Biol., 10, 1363-1376, 2004.

Skopp, J., Jawson, M. D., and Doran, J. W.: Steady-state aerobic microbial activity as a function of soil-water content, Soil Sci. Soc. Am. J., 54, 1619-1625, 1990.

Sotta, E. D., Meir, P., Malhi, Y., Nobre, A. D., Hodnett, M., and Grace, J.: Soil $\mathrm{CO}_{2}$ efflux in a tropical forest in the central Amazon, Glob. Change Biol., 10, 601-617, 2004.

Tang, X. L., Liu, S. G., Zhou, G. Y., Zhang, D. Q., and Zhou, C. Y.: Soil-atmoshpheric exchange of $\mathrm{CO}_{2}, \mathrm{CH}_{4}$ and $\mathrm{N}_{2} \mathrm{O}$ in three subtropical forest ecosystems in southern China, Glob. Change Biol., 12, 546-560, 2006.

van Ginkel, J. H., Gorissen, A., and Polci, D.: Elevated atmospheric carbon dioxide concentration: effects of increased carbon input in a Lolium perenne soil on microorganisms and decomposition, Soil Biology and Biochemistry, 32(4), 449-456, 2000.

Wen, D. Z., Wei, P., Kong, G. H., Zhang, Q. M., and Huang, Z. L.: Biomass study of the community of Castanopsis chinensis + Cryptocarya concinna + Schima superba in a southern China reserve, Acta Ecologica Sinica, (in Chinese with English abstract), 17(5), 497-504, 1997.

Whittake, R. H. and Woodwell, G. M.: Dimension and production relations of trees and shrubs in the Brookhaven forest, New York, J. Ecol., 56, 1-25, 1986.

Xu, Y. G., Zhou, G. Y., Lou, T. S., Wu, Z. M., and He, Z. C.: Soil solution chemistry and element budget in the forest ecosystem in Guangzhou, Acta Ecologica Sinica, (in Chinese with English abstract), 21, 1760-1861, 2001.

$\mathrm{Xu}, \mathrm{M}$., and Qi, Y.: Spatial and seasonal variations of $\mathrm{Q}_{10}$ deter- 
mined by soil respiration measurements at a Sierra Nevadan forest, Glob. Biogeochemistry Cy., 15(3), 687-696, 2001.

Zak, D. R., Pregitzer, K. S., King, J. S., and Holmes, W. E.: Elevated atmospheric $\mathrm{CO}_{2}$, fine roots and the response of soil micro organisms: a review and hypothesis, New Phytol., 147, 201-222, 2000.

Zhang, D. Q., Sun, X. M., Zhou, G. Y., Yan, J. H., Wang, Y. S., Liu, S. Z., Zhou, C. Y., Liu, J. S., Tang, X. L., Li, J., and Zhang, Q. M.: Seaaonal dynamics of soil $\mathrm{CO}_{2}$ effluxes with responses to environmental factors in lower subtropical forest of China, Science in China Series, Dokl. Earth Sci., 49 (Suppl. II), 139-149, 2006.
Zheng, X. H., Fu, C. B., Xu, X. K., Yan, X. D., Huang, Y., Han, S. H., Hu, F., and Chen, G. X.: The Asian nitrogen cycle case study, AMBIO, 31, 79-87, 2002.

Zheng, Z. M., Yu, G. R., Fu, Y. L., Wang, Y. S., Sun, X. M., and Wang, Y. H.: Temperature sensitivity of soil respiration is affected by prevailing climatic conditions and soil organic carbon content: A trans-China based case study, Soil Biology and Biochemistry, 41, 1531-1540, 2009. 